\title{
Problems of innovative development of the system of Ukraine
}

\section{Tamara Berezianko}

\author{
National University of Food Technologies, Kyiv, Ukraine
}

\section{Keywords:}

Innovation

Development

Business

Ukraine

\section{Article history:}

Received

14.09.2018

Received in

revised form

17.11.2018

Accepted

03.12 .2018

\section{Corresponding author:}

Tamara

Berezianko

E-mail:

berezianko-

2016@bigmir.net

DOI:

$10.24263 / 2310-$

1008-2018-6-2-10

\section{Abstract}

Introduction. The aim of this recearch is to identify the main disproportions of the development management of the national innovation system.

Materials and methods. The materials of the research contain the analysis of development state of the Ukrainian innovation system. The national innovation system is considered in the context of compliance with the international measurements and the concept of transition to the formation of knowledge society. It have been used the method of comparison, system analysis as well as survey. A logical-abstract method was used to group national and international analytical results.

Result and discussion. It is proved, that the main restrictive factor while forming of comprehensive whole and developing of its breakthroughs is inconsistent, and sometimes destructive management, insufficient activity of public administration and residual financing of needs. In the state administration and research environment of Ukraine there are somewhat opposite ideas about the state and needs of further innovation development. Public officials consider it necessary to put science at the service of the immediate business needs in order to strengthen the country's position on the international market and increase overall competitiveness. This, in turn, serves the purpose of implementing the tasks entrusted to the government by international financial donors. For its part, the scientific environment defends the long-term goals of preserving the country's scientific, technological and innovative potential. Support for fundamental research does not bring a quick result, but it preserves opportunities for development for future generations. In view of this, it is critical to address the call of functionaries to reformat the directions of the market to meet market demand and the current needs of the real sector of the economy. The discrepancy in approaches to scientific innovations and the directions of their implementation is reflected in the scope of state financial and organizational support. To fund the innovation development fund in 2018, only \$2 million has been allocated. The second issue of the country's innovation development is the lack of development of national legislation, especially in modern areas, such as the creation of innovative ecosystems. In general, this can be diagnosed as a consequence of an institutional destructive policy at the state level. The scientific activity is not included into the list of state priorities: there is a constant reduction of funding both for institutions and scientific research.

Conclusions. Forming of an effective and competitive national innovation system requires the legislative and tool consolidation of innovative development of the country, creation and structuring of the innovation market under national control. 


\section{Introduction}

The world market community has began to focus on the convergence of the public and business interest since the 90 's. At first the society had such tasks and motivations as: creation of favourable climate for the entire business; soft investments in the infrastructure (personnel training, improvement of regulations); development of partnership between the state and private sector; private sector invests in the common weal; priority of target domestic investments, strengthening of competitive advantages in the corporate sector (priority of public sector). According to the tasks the state used the following tools: global strategy of competitive development and stimulation of increase in local firms; support of intercommunity network consolidation and cooperation; promotion of economic interdependence of corporate groups; improvement of quality of labor resources; efforts to improve the quality of life of the society.

The purpose of the study consists in identification of problems of creation and implementation of scientific knowledge, technologies, provision of innovation process and functioning of national innovation system.

The above-mentioned conditioned consideration and critical analysis of the following tasks: efficiency of state regulation of innovations; problems of implementation of innovations in the national education; the quality of knowledge generation and their direction; research of innovation infrastructure; as well as the level of innovation of national production. Object of the study. The components of the national innovation system.

\section{Materials and methods}

In the process of preparation of the article scientific and analytical researches of national and foreign statistical, financial and rating organizations were used, as well as the results of their own interviews and questionnaires were processed.

The methodology of the study included statistical analysis, grouping, systematization, sociological surveys, questionnaires and special tools for processing personal data. The logic of presentation of the material follows the structure of the national innovation system. The logic of the study is subordinated to the task of analyzing the constituent parts of the national innovation system.

\section{Results and discussion}

The national innovation system includes the following elements:

1. State regulation (legislative, structural and functional institutions);

2. Education (institutions of higher education and scientific production enterprises);

3. Generation of knowledge (research institutions and organizations);

4. Innovative infrastructure (production, technological, financial, informational, analytical, expert and consulting components, including industrial parks, technopolises, innovation centers, technology transfer centers, etc.);

5. Production.

However, due to the development of human capital Ukraine received the 31st place, that corresponds to the level of development of developed market countries. Productivity is one of the most effective tools of increase and development. And the best tool of its accumulation is the use of innovative tools for the development of potential. 
According to the Global innovation index Ukraine ranked the 50th place among 127 countries in 2017 [1-3]. Human capital is the main part of national competitiveness: the country ranked the 41 st place. The main restraining element is the low of R\&D expenditures (54th place in the ranking) that cause the migration of existing and potential scientists outside Ukraine.

According to the index of "Institutions" Ukraine received the 101st place, according to the level of development of infrastructure - 90th place, according to the indicators of markets effectiveness- 43.2 or 81 st place (trade and competition - 48, credits - 71, investment - 107), according to the "business experience" index - 51st place (according to the number of brain workers -41 st place, according to the innovative knowledge $-72 \mathrm{~d}$, according to the knowledge perception $-63 \mathrm{~d}$ place). At the same time the country demonstrates a high level of research efficiency - 32nd place and a low-impact of its implementation - 77. Quite high is the index value of "creativity" - 49th place, online creativity - 47th place. According to the global competitiveness index Ukraine has received the 82nd place between Brazil and Bhutan.

According to the criteria, the score of Ukraine is: the share of expenditures on research activities in GDP - 47; the effectiveness of industry - 48; growth of GDP per capita of the adult population for three years - 50; percentage of local high-tech companies in the business of the country as a whole -32 ; the effectiveness of higher education -21 ; concentration of scientists -46 ; patent activity -27 [4].

For reference: the effectiveness of education is calculated as the proportion of graduates graduating from higher education institutions to the share of graduates with engineering and technical education. In the western market countries university education is considered to be a part of academic one and humanities. And the competitive advantage of the country is mainly obtained by technical and technological advantage. Then the methodical approach becomes clear. There was the period of 1990-95's in the history of market economy of Ukraine, when namely the market transformation caused the situation, when the engineering specialists were not engaged into the non-specialized employment. For 20 years it was impossible to get actual and decent employment in the engineering profession. As a result people are not interested in technical education in the country (in 2017 only 3 applications were submitted to the Faculty of Mechanics at the National University of Food Technologies). This situation reflects the structural changes in the economy and resulted in to the country's de-industrialization. The lack of attention to the technical professions is formed in society and is reflected in family education (parental attitude, negative public experience and media neglect) and schools (lower quality of teaching of exact sciences, especially in towns and villages, lack of out-of-school encouragement through public circles of technical development and lack of material and technical base for their functioning).

This conclusion agrees with the data of sociological research conducted by the leading national agencies. The destruction of social growth through education and ability to use skills in working practice force youth to focus on the societies with a defined and formalized program for acquiring a high social status.

Ukraine received the 35 th place according to the rating of compulsory education, the 45 th place according to the number of researchers, according to the quality of scientific institutions - the 41 st place, according to the employment - the 27 th, but legal regulation of labor market remains to be the the main problem - the 103rd place. 
Guidelines of social growth, $\%$

\begin{tabular}{|l|c|c|c|c|c|c|}
\hline \multirow{2}{*}{ Response } & \multicolumn{3}{|c|}{ Ukraine } & \multicolumn{3}{c|}{ EU } \\
\cline { 2 - 7 } & $\mathbf{2 0 0 9}$ & $\mathbf{2 0 1 2}$ & $\mathbf{2 0 1 6}$ & $\mathbf{2 0 0 9}$ & $\mathbf{2 0 1 2}$ & $\mathbf{2 0 1 6}$ \\
\hline High intelligence & 30.3 & 31.8 & 36.6 & 56.1 & 60.8 & 60.1 \\
\hline $\begin{array}{l}\text { Ability to circumvent the } \\
\text { law }\end{array}$ & 33.1 & 33.1 & 29.2 & 5.3 & 5.5 & 4.7 \\
\hline $\begin{array}{l}\text { Social status of the } \\
\text { family (origin) }\end{array}$ & 37.9 & 38.6 & 33.9 & 24.2 & 22.5 & 14.9 \\
\hline Good education & 25.8 & 26.4 & 20.7 & 49.0 & 48.4 & 52.2 \\
\hline $\begin{array}{l}\text { Focus on enrichment, } \\
\text { individualism }\end{array}$ & 46 & 45 & 42 & 47 & 43 & 42 \\
\hline $\begin{array}{l}\text { Possibility of self- } \\
\text { realization in own } \\
\text { country }\end{array}$ & 66 & 56 & 32 & 83 & 86 & 88 \\
\hline $\begin{array}{l}\text { Confidence in } \\
\text { government }\end{array}$ & 35 & 48 & 34 & 67.3 & 70.2 & 78.3 \\
\hline $\begin{array}{l}\text { Importance of science in } \\
\text { society }\end{array}$ & 33 & 33 & 58 & 67 & 72 \\
\hline $\begin{array}{l}\text { Authority take into } \\
\text { account the } \\
\text { recommendations of } \\
\text { national science }\end{array}$ & & & & & & \\
\hline
\end{tabular}

Based on the sources [5]

The position of Ukraine in the "Innovation" rating became worse, except for the index of "Availability of scientists and engineers." The worst position is in category "Government procurement of high technologies and products" - from the 86th place to the 92nd, as well as in the category of "Relations between university and industry" - from the 57th to the 73rd place. And the only positive trend is in the category "access to the Internet per 100 people".

In general, this is a consequence of an institutional destructive policy at the state level.

Meanwhile, Ukraine has exclusive positive examples that have been implemented counter to the situation: 7 Ukrainians are among the top 100 of the best innovators in Europe in robotics, biosensories and computer literacy, production of power efficient homes, HR technologies, media and Internet tools [3].

Analysts note the lack of an integral management system of the national innovation system: the functions are allocated between the Ministry of Education and Science of Ukraine and the Ministry of Economic Development and Trade of Ukraine. As a result, there is no coordination between the investment policy and innovation projects. Moreover, a significant number of restrictive measures of the Ministry of Finance of Ukraine hinders the implementation of innovations and hinders the development of scientific and technical capacity.

However, there are positive improvements: in 2016 a separate National Committee for Industrial Development was created, in 2017 the National Council of Ukraine for Science and Technology Development and the Council for Development of Innovation were formed. However, their activities are not coordinated. As a result, it is not possible to ensure effective impact on the Government's decisions on the development of innovations. 


\section{- Economics and Management -}

The identified problems become worse at the regional level.

Many elements of the innovation infrastructure don't work, innovation parks and incubators are closed (in 2005 the system of scientific and technological preferences has been suspended in terms of legislation). Legislative proposals on improvement and development of innovation activities have been refined and marked up for many years.

According to the index of Global talent Ukraine has got a high rating. Human resources are always characterized by a high level of qualification. Perhaps, therefore, Ukraine has become one of the largest exporters of labor (more than 2 million citizens work abroad). The number of students and institutions of higher education is decreasing: in 2017 only 1369,4 students studied at 287 institutions of higher education. These indexes are $35 \%$ and $17 \%$ respectively less than the same indexes in 2010 . For many years no more than $10 \%$ of the national investments are allocated to the university science (15 million a year).

In 2016 an external audit of the Ukrainian innovation and research system was launched in Brussels. International experts observed an extremely unsatisfactory state of national innovation system. The participation of the private sector at the level of $20 \%$ of the total expenditure in the state on science is very low in comparison with its corporate capabilities. Basic machine building has turned from development driver into a deterrent factor, that hinders innovation mechanisms.

Experts underlined, that Ukraine belongs to the countries with the highest level of "superfluous education": in the final document they wrote, that $80 \%$ of young people study at universities. And it is too much for Ukraine. This document was approved by the Ministry of Education and Science of Ukraine. The level of "superfluous education" is the highest in economic and legal sciences. At the same time the entrants are not interested in natural and technical sciences. In addition, the national economy is not able to admit such a large number of highly skilled people, on the contrary, there is lack of semiskilled specialists with technical qualifications. At the same time, the percentage of students, who continue their postgraduate study is too low in accordance with the European standards [6].

During the independence years, nobody has created proper conditions for the development of science and for the introduction of innovations. Expenditures of the state budget for research make only $0,22 \%$ of GDP. Although the developments of domestic scientists are annually sent to the Cabinet of Ministers of Ukraine and ministries only a few inventions are realized practically. However, world experience shows, that the results of scientific research are not able to be effectively and quickly realized only on the market basis without significant state support.

National science operates within the 6th technological paradigm, and $94 \%$ of production consist of the 3rd paradigm with the elements of the 4th and 5th ones. It is impossible to change this situation without active intervention and strategic purposeful work of the state, because business (both large and small) exploit the natural raw material base of the country and is aimed at getting maximum results in a short time.

The enterprises producing food products, beverages and tobacco products carried out the most active innovative activities $-21,6 \%$.

These industries are interested in the wide range of products, expansion of markets, improvement of quality, introduction of new technologies, receipts and equipment. The enterprises of these industries focus on private investment opportunities with a rare involvement of international loans from foreign co-owners. The leading industry experts think, that it is necessary to create more scientific and technical centers, provide access to favorable financing in order to activate innovation activity. The food industry as well as other industries mainly use own resources at the level of $75 \%$. 


\section{- Economics and Management}

Analysts note, that a significant share of innovative activities involves marketing and management technologies. The trade and service sector applies marketing and management technologies rather than technological innovation. First of all, it is about the means of product promotion, PR and HR activities, electronic commerce, logistics and motivation of personnel. $5,6 \%$ of funds allocated for innovation were spent on financing of this direction.

Over the last 5 years budget financing of strategic priorities of innovative activity was carried out in the following areas: technological innovation and development of agroindustrial complex $-59,4 \%$; the smallest financing was in the direction of the introduction of new technologies and equipment for quality medical service, treatment and pharmaceutics $-2,6 \%$. At the same time, the total funding budget was fulfilled only by $75,5 \%$. The funding of medium-term priorities was fulfilled by $74,2 \%$. At the same time, the funding was reduced by $40 \%$ of the annual volume in 2014 .

For the period of 2012-2016 5671 technologies were created at research institutions for budget funds. Only $10.8 \%$ of these technologies were transferred to industrial enterprises and $0,8 \%$ were sold on the external markets. During this period 36 advanced technologies were purchased for budget funds. $97,5 \%$ of these technologies were purchased in 2012. It should be noted a significant deterioration in the relationship between the number of implemented technologies and innovative products. In 2000 this ratio averaged 1:10,92, in 2005 - only $1: 1,74$, and in 2017 - only $1: 1,09$ [7].

For almost 20 years there were two peaks of innovative financing in Ukraine: in 2007 due to the external borrowings of the owner and in 2011 due to external arrangements, partnerships and external investment. The latter allowed us to double the level of funding of innovation activities in the industry. But in the period of 2006-2016 the share of innovative enterprises in industry was steadily decreasing. Such situation proves, that there are no necessary prerequisites for the functioning of the investment-innovative model of development in Ukraine. The reason for this is the fact, that the realization of competitive advantages created due to the high-tech products in the domestic industry is almost absent. At the same time, this situation leads to a high risk of investment in innovation. As a result the cash flows decrease. Investors choose the less risky traditional industries: today $75 \%$ of investments in Ukraine are in the industry of the 3rd paradigm, 20\% in the 4th paradigm and $4,5 \%$ in the 5 th paradigm. The industries of the $3 \mathrm{rd}$ technological paradigm have the highest level of re-equipment and modernization - $83 \%$, and the industries of the 4 th paradigm - only $10 \%$.

In the period of 2000-2004 the State Statistics Service of Ukraine conducted surveys of managers of industrial enterprises regarding the reasons for low innovation activity. We have carried out own research in the period of 2007-2016. But our sample was significantly smaller.

Having analyzed the results of the survey and the data of scientific observations and statistics, we reached the following conclusion:

1. In the entire period from 2000 to 2016 the matter of financing was not settled. Attraction of venture, loan and other market resources was limited and speculative, and ensured only "skimming". The received profit was taken out of the country regardless of the source of income $(80 \%$ of the revenues came from offshore sources for short-term funding of developments that are complete by $80 \%$ ).

2. Legislation and public administration are situational and preferential. The author has investigated this question in many publications.

3. Non-market forms of restraint became barriers: opportunism of the owner, greed effect, resource orientation of the markets in the country. 
Main obstacles to the innovation activity of enterprises (survey results), $\%$

\begin{tabular}{|c|c|c|c|c|}
\hline \multirow[t]{2}{*}{ Factors of negative influence } & \multicolumn{2}{|c|}{$\begin{array}{l}\text { According to the } \\
\text { IFC }\end{array}$} & \multicolumn{2}{|c|}{$\begin{array}{l}\text { The answers of } \\
\text { managers of } \\
\text { enterprises }\end{array}$} \\
\hline & $\begin{array}{l}2000- \\
2004\end{array}$ & $\begin{array}{l}2007- \\
2016\end{array}$ & $\begin{array}{l}2000- \\
2004\end{array}$ & $\begin{array}{l}2007- \\
2016\end{array}$ \\
\hline The lack of funding & 75 & 23 & 86 & 92 \\
\hline $\begin{array}{l}\text { Customers don't have enough } \\
\text { money }\end{array}$ & 50 & 12 & 40 & 50 \\
\hline $\begin{array}{l}\text { Underdevelopment of finance and } \\
\text { credit system/high credit rates }\end{array}$ & 42 & 22 & 39 & 50 \\
\hline Imperfect legislation & 25 & 15 & 32 & 38 \\
\hline Undeveloped raw materials base & 15 & 15 & 29 & 29 \\
\hline High economic risk & 30 & 18 & 24 & 28 \\
\hline Low demand & 8 & 10 & 15 & 34 \\
\hline Lack of international relations & 25 & 12 & 11 & 12 \\
\hline Strict/preferential state regulation & 28 & 10 & 15 & 29 \\
\hline Corruption & 10 & 38 & 12 & 22 \\
\hline Bad public administration & 36 & 22 & 12 & 28 \\
\hline Owner's/investor's reluctance & 6 & 6 & 15 & 34 \\
\hline
\end{tabular}

Based on statistics and own surveys

The process of basic adjustment and modernization of the enterprises requires the use of special means of support : government support, tax and procedural benefits, creation of special zones and incubators. All developed countries did everything in the same way. However, the international community has called Ukraine for structural changes, modernization of equipment and production technologies and simultaneously it ha strongly demanded abolition of preferences and economic support measures: the World Bank, rating agencies, intergovernmental meetings, the International Monetary Fund have repeatedly emphasized these demands in their documents. The severest demands were in the periods, when Ukraine tried to join the global funding at the state level (IMF requirements on the eve of the receipt of loans), to enter the international market organizations (2005 WTO and 2014 the Association agreement with the EU). Because of such leverage Ukraine has reorganized the State innovation Fund into the State innovation credit institution (2000); suspended, the adopted in 1999 law of Ukraine "On special regime of innovation activity of technological parks" has been abrogated (2005). Thus Ukraine doesn't have own tools to support the national innovation production. But the industrial parks started to operate. They were based on foreign investment and foreign control of selection of directions of innovations and areas of application of innovative production (2006). At the same time the innovative developments were implemented with help of business incubator (creation of prototype, current engineering model) through financing of venture and private investment funds. The objective "organization of development, production and put science intensive, high-tech products on Ukrainian and foreign markets" [8]. The change of economic orientation of the country made it possible to restart the activities of industrial parks (2012), to create jobs, to 
development modern production infrastructure. At that time, there were more than 30 industrial parks.

In recent years the number of institutions of scientific and technical information has been substantially reduced, the number of regional centers of scientific and technical information has been reduced or their subordination has been changed, the Ukrainian Center for Scientific and Technical Information has been reorganized, its resource support has been weakened, therefore the information resource does not conceptually and organizationally meet the needs of the innovative economy.

The integrity of the development of the National innovation system. The issues of formation and development of national innovation system periodically become the object of consideration at the Parliamentary hearings. In 2007 such hearing was held for the first time. In 2009 the "Strategy of innovation development of Ukraine for the period of 2010-2020 under the conditions of globalization challenges" was discussed and the Concept of development of the national innovation system for 2009-2013 was approved. Even at the level of higher state authorities this period is recognized as the most productive. This period is characterized by a consolidated governmental approach to the needs of innovative development of the economy.

At present, there are two programs documents on innovation development in Ukraine: Sustainable Development Strategy "Ukraine 2020", the program of activities of the Cabinet of Ministers of Ukraine on implementation of the Association Agreement between Ukraine and the EU. The Plan of measures on the implementation of the Concept of reformation of the state policy in the innovation sector for 2015-2019 is aimed at the realization of these directions. In accordance with the Plan it is necessary to develop strategies for the development of high-tech industries, as well as a number of specified laws. The process of approval of the bills continues for more than two years. The National Academy of Sciences is trying to compensate for sluggishness or inactivity: there was a report "Civilizational Choice of Ukraine: Paradigm of Understanding and Action Strategy", "Innovative Ukraine 2020". The program "Foresight" has been developed. It is a program of innovation and investment development of NAAS for 2016-2020. And the Mechanism of implementation of this Program has been also developed. All these data were submitted to the Cabinet of Ministers of Ukraine. These documents are being processed since 2016.

Meanwhile, Ukraine continues to lose its competitive position in the markets of high-tech goods and services. According to the State statistics service of Ukraine $75 \%$ of patents of national owners are no longer valid because of non-payment of fees to maintain efficiency, only $7 \%$ of patents are used in the economy. The reason is the lack of incentives, long-term and resource consuming method of registration. As a result, there is a process of "patent migration", which is annually at the rate of $10-12 \%$. This process is particularly characteristic for the direction of development of medicines, IT technologies and for pharmacology [7,9].

Moreover the imbalances in the training of specialists are increasing: there are three times more lawyers and economists than specialists, that are able to generate new knowledge, specialists in physics, mathematics and advanced technology and specialists, that are able to provide innovative development of economy.

\section{Conclusions}

Having analyzed the state of the national innovation system we have found a number of negative factors that hamper its development. These negative factors include slippery political decisions, reduction of governmental attention. These factors have influenced the 


\section{- Economics and Management}

type of managerial decisions, prioritization, funding, legislative support. Particularly urgent is the inadequate regulation in the area of intellectual property. There are also problems of commercial implementation of scientific research results. It is caused by disinterest of rental business, poor infrastructure and lack of support in the processes of international registrations of intellectual property rights to the inventions.

The vast majority of innovative solutions are considered without regard for the prospects. Only business aspect and the rate of recoupment of investments are mostly taking into account. Unfortunately, the scientific activity is not included into the list of state priorities: there is a constant reduction of funding both for institutions and scientific research. At the same time, this situation leads to negative shifts in personnel, promotes the outflow out of the country of talented young people and well-known experts. The scientific potential of Ukraine is almost excluded from the economic and management process of the society - the science intensive capacity of industrial production is at the rate of only $0,3 \%$, the knowledge management capacity of commercial structures $-2 \%$, public administration $-5 \%$. This situation creates a steady lag in technical and technological directions of development and establishes the raw material orientation of the national economy for the future [9].

The revival of scientific and technological power of Ukraine, strengthening of its competitiveness and formation of powerful national innovation system is observed in several directions:

- renewal of the value of science and innovation at the level of state policy, including the formation of the strategy of innovative development, activities, execution of tasks in form of Program with independent funding;

- implementation, legislative and instrumental securing of innovative development of the state on the basis of formation of innovative market under the control and accountability of the executive power of the country, region, industry.

Implementation and realization of these tasks requires not only political will, continuity of governmental policies but also creation of systemic approach based on strategic vision, development prospects and international cooperation, legislative regulation. Fulfillment of tasks requires improvement of the state management of innovation processes in the state, proper economic support, improvement of forecasting system for long-term outlook, target priorities and improvement of education srystem, preservation and support of scientific personnel of the state.

\section{References}

1. Innovation Union Scoreboard 2017 (2017), Available at: http://ec.europa.eu/enterpraise/policies/innovation/files/ius/ius-2017_en.pdf

2. Europa 2020. A strategy for smart, sustainable and inclusive grouth. $\overline{C O M}(2010) 2020$ final. Official Jornal of the European Union URL, Available at:- http://eurlex.europa.eu/legal-content/EN/TXT/PDF/?uri=CELEX:52010DC2020\&from=en

3. Global Innovation Index (2017), Available at: http:/www.globalinnovatioindex.org/gii-2017-report

4. Global Competitiveness Report 2017-2018, Available at: http://www.3.weforum.org/docs/GCR2017-2018/05FullReport/ TheGlobalCompetitivenessReport2017-2018.pdf

5. Zlobina O.H., Kostenko N.V., Shulha M.O. and others (2017), Stan suchasnoho ukrainskoho suspilstva: tsyvilizatsiinyi vymir, The state of contemporary Ukrainian society: the civilizational dimension, Institute of sociology of NAS of Ukraine, Kyiv. 


\section{- Economics and Management}

6. Sim ukrayintsiv uvijshly do New Europe 100 - rejtyngu 100 innovatoriv Yevropy, Seven Ukrainians are in New Europe 100 - a ranking of 100 innovators of Europe, Available at: https://kfund-media.com/sim-ukrayintsiv-uvijshly-do-new-europe-100rejtyngu-100-innovatoriv-yevropy/

7. Dryha S.G. (2017), Innocide instead of innovation policy, Problems and prospects of development of innovation activity in Ukraine: the 10th international business-forum, Kyiv National Trade and Economic University, pp. 59-61

8. Pyrozhkov S.I. (2004), Modeli i stsenarii strukturno-innovatsiinoi perebudovy ekonomiky Ukrainy, Models and prospects of structural-innovative reconstruction of the economy of Ukraine, Kiev, Investment and innovative strategy of development of the national economy OIE NAS of Ukraine

9. Parliamentary hearings: National innovation system: state and legislative support of development (21.03.2018), Available at: http://rada.gov.ua/fsview/156131.html

10. Jorge A. Rodriguez, Frank Wiengarten (2017), The role of process innovativeness in the development of environmental innovativeness capability, Journal of Cleaner Production, 142(4), pp. 2423-2434

11. Natalya Kalenskaya (2015), The Formation of the Model of the Infrastructural Ensuring of Regional Innovative Development, Procedia-Social and Behavioral Sciences, 177, pp. 203-208

12. Fakhrutdinova E., Shigabutdinov A., Safina L., Fakhrutdinov R. (2015), Institute of Social Security as A Factor of Innovative Development of The Petrochemical Complex, Procedia Economics and Finance, 23, pp. 757-762

13. Shamil M. Valitov, Almaz Kh. Khakimov (2015), Innovative Potential as a Framework of Innovative Strategy for Enterprise Development, Procedia Economics and Finance, 24, pp. 716-721

14. Ustinovich I.V. (2018), Substantiation of New Products' Mastering as the Main Element of Industrial Organizations' Innovative Development, Ekonomicheskie i sotsialno-gumanitarnye issledovaniia, 1(17), pp. 46-55.

15. Zsuzsanna K. Szabo, Emilia Herman (2012), Innovative Entrepreneurship for Economic Development in EU, Procedia Economics and Finance, 3, pp. 268-275

16. John M. Woodley (2018), Chapter 3: Innovative process development and production concepts for small-molecule API manufacturing, Computer Aided Chemical Engineering, 41, pp. 67-84 